\title{
Biodiversity and temporal patterns of macrozoobenthos in a coal mining subsidence area in North China
}

\author{
Guanxiong Zhang ${ }^{1,2,3}$, Xingzhong Yuan ${ }^{\text {Corresp., 1, 2,3 }}$, Kehong Wang ${ }^{1,2,3}$ \\ ${ }^{1}$ Chongqing University, State Key Laboratory of Coal Mine Disaster Dynamics and Control, Chongqing, China \\ 2 Chongqing Key Laboratory of Wetland Science Research in the Upper Reaches of the Yangtze River, Chongqing, China \\ 3 Institute of Chongqing Qianzhou Ecological Research, Chongqing, China \\ Corresponding Author: Xingzhong Yuan \\ Email address: 1072000659@qq.com
}

Coal resources play a strategic role in the long-term development of China. Large-scale mining has a considerable impact on the landscape, and it is a long-term heritage of industrialization and unique to the Anthropocene. We investigated the macrozoobenthos and water in nine mining subsidence wetlands at different developmental stages (3-20 years) in North China. A total of 68 species were found, and the macrozoobenthos community in the newly formed wetlands showed high diversity. We believe that this high diversity is not random; rather, the high diversity was because of the special origin and development of the wetland. We used three time slices from the timeline of the development of the newly formed wetlands and compared them. It was found that the macrozoobenthos community was significantly affected by the change in the subsidence history. We emphasize that coal mining subsidence should not be merely identified as secondary man-made disasters, as they are often secondary habitats with high conservation value, and their conservation potential lies in the fact that these secondary habitats can replace rapidly decreasing natural wetlands. 
1 Biodiversity and temporal patterns of macrozoobenthos in a

2 coal mining subsidence area in North China

3

4 Guanxiong Zhang ${ }^{1,2,3}$, Xingzhong Yuan ${ }^{1,2,3^{*}}$, Kehong Wang ${ }^{1,2,3}$

6 1. State Key Laboratory of Coal Mine Disaster Dynamics and Control, Chongqing University,

7 Chongqing, 400030, China

8 2. Chongqing Key Laboratory of Wetland Science Research in the Upper Reaches of the Yangtze

9 River, Chongqing, 401331, China

10 3. Institute of Chongqing Qianzhou Ecological Research, Chongqing, 400050, China

Corresponding Author:

Xingzhong Yuan

State Key Laboratory of Coal Mine Disaster Dynamics and Control, Chongqing University, Chongqing, 400030, China

Email address: 1072000659@qq.com

\section{Abstract}

Coal resources play a strategic role in the long-term development of China. Large-scale mining has a considerable impact on the landscape, and it is a long-term heritage of industrialization and unique to the Anthropocene. We investigated the macrozoobenthos and water in nine mining subsidence wetlands at different developmental stages (3-20 years) in North China. A total of 68 species were found, and the macrozoobenthos community in the newly formed wetlands showed high diversity. We believe that this high diversity is not random; rather, the high diversity was because of the special origin and development of the wetland. We used three time slices from the timeline of the development of the newly formed wetlands and compared them. It was found that 
the macrozoobenthos community was significantly affected by the change in the subsidence history. We emphasize that coal mining subsidence should not be merely identified as secondary man-made disasters, as they are often secondary habitats with high conservation value, and their conservation potential lies in the fact that these secondary habitats can replace rapidly decreasing natural wetlands.

\section{Introduction}

Coal resources play a strategic role in the long-term development of China. The rapid development of the social economy has resulted in an increased demand for energy. Thus, coal mining activities have become more intense. In 2014, coal production reached 38.7 billion tons, accounting for $49 \%$ of the world's gross domestic product (The National Bureau of Statistics of the People's Republic of China); of this, more than $92 \%$ of the coal comes from underground mining, which leads to serious surface subsidence. It has been estimated that when 10,000 tons of coal is mined underground, the settlement area spans $0.20 \sim 0.33$ hectares. In China, the annual subsidence is expected to increase by 2104 hectares (Hu \& Xiao, 2013). High groundwater coal basins are mainly distributed in the eastern and northeast parts of China. There are many thick coal seams with high groundwater levels and flat terrain. Most of these areas overlap coal seams and agricultural production sites. After coal mining, the upper roof of the mine is broken, resulting in changes in the original geological structure; this process further induces ground subsidence, and a large amount of mine subsidence water covers areas and has high depths, i.e., up to $13 \mathrm{~m}$ in some places. The groundwater will appear if the basin surface subsides to the phreatic water surface (Zeng et al., 2016). After coal mining subsides, the subsidence pond forms a subsidence lake. Under flooding conditions, submerged soil gleying occurs, wetland plants are formed, and typical "mining subsidence wetlands" (MSWs) are formed.

$$
\text { In stark contrast to valuable habitats such as natural wetlands, coal mining subsidence often }
$$
reforms the environment, greatly limiting environmental recovery. In this case, it is impossible to maintain the original environmental attributes or to maintain the native species pools, which 
means that the succession process of the organism basically starts from an initial (or primitive) stage (Suding et al., 2004). However, some studies have reported that the temporal structural changes of macrozoobenthos (Layton \& Voshell, 1991; Christman \& Voshell, 1993; Cristina et al., 2016) in newly formed ponds reach a high density several months after the ponds are filled, and macrozoobenthos become an important food source for benthic fish (Solimini et al., 2003). However, research on the macrozoobenthos community in coal mining subsidence areas is scarce.

Macrozoobenthos, as a potentially important driver of metabolism in freshwater ecosystems, have traditionally been considered a food source for benthic fish and consumers of algae and organic matter (Janse et al., 2010; Vander Zanden \& Gratton, 2011). Specifically, macrozoobenthos provide an important link between primary producers and secondary consumers, play an important role in the nutritional cycle, and promote the decomposition of organic matter through consuming and decomposing plant and animal tissues (Irons et al., 1988). This community is also an ideal biological indicator of the aquatic ecosystem (Mereta et al., 2013; Chang et al., 2014; Hong et al., 2014) because of the following characteristics (Burgmer et al., 2007; Schilling et al., 2009; Villnäs \& Norkko, 2011; Kappes \& Haase, 2012; Hölker et al., 2015): diverse species, poor swimming ability, sensitivity to environmental change and ease of collection.

It is generally assumed that the degree of anthropogenic influence is negatively correlated with the health of the macrozoobenthos community. In industrial and post-mining areas, the lower biodiversity is assumed to be related to the surrounding natural habitats (Baasch et al., 2012; Hendrychová et al., 2012; Pérez-Bilbao et al., 2015; Podgorska, 2015). Man-made (i.e., secondary) habitats can increase the diversity of habitats within the local area and can replace the original habitat. There are a large number of studies showing that human disturbance on natural habitats has a negative impact on the taxonomic diversity, but it is surprising that environmental changes caused by human activities may indirectly lead to the establishment of heterogeneous habitats (Samways, 1989; Tropek et al., 2010; Dolny \& Harabis, 2012; Chester \& Robson, 
2013). A large number of heterogeneous patches (habitats) have developed because of the direct or indirect results of surface (Tropek et al., 2010) and sub-surface mining (Dolny \& Harabis, 2012). These habitats are often regarded as local diversity hotspots for terrestrial and freshwater invertebrates, including threatened and endangered species (Benes et al., 2003; Tropek et al., 2010; Dolny \& Harabis, 2012).

For some species, post-mining habitats are the only suitable habitat within a vast area (Harabis \& Dolny, 2015). It has been speculated that individual species have different sensitivities to the characteristics of individual habitats and that they can be discovered at a particular location only when the environment meets their unique habitat requirements (Lubertazzi \& Ginsberg, 2009; Ball-Damerow et al., 2014). Increasingly, research indicates that the initial environmental characteristics may affect the biodiversity in a region and that the initial characteristics of the newly formed environment may have a significant impact on the subsequent succession processes (Prach \& Pyšek, 2001). Therefore, from the perspective of environmental conservation, we are eager to understand these processes and initial habitat characteristics, which may have a significant impact on the biodiversity and conservation value of newly developed wetlands in coal mining subsidence areas. The purpose of this study was to determine the general pattern of macrozoobenthic communities in freshwater wetlands in coal mining subsidence areas. We designed four research purposes in combination with data: (1) studying the species composition and diversity of the macrozoobenthic community in MSWs; (2) studying the temporal pattern of macrozoobenthos at different developmental stages in MSWs; (3) assessing the impact of environmental variables on the diversity and conservation of these secondary habitats; and (4) proposing appropriate management recommendations based on the synthesis of this knowledge.

\section{Materials \& Methods}

\section{Study area}

The study area is located in Yanzhou City $\left(116^{\circ} 50^{\prime} \mathrm{E}-116^{\circ} 55^{\prime} \mathrm{E}, 35^{\circ} 30^{\prime} \mathrm{N}-35^{\circ} 25^{\prime} \mathrm{N}\right)$, Shandong Province, which is an important coal production base in China (Fig 1). Shandong Province's 
climate is typical temperate monsoon climate characterized by hot and rainy summers and cold and dry winters, with an average annual precipitation of $600 \mathrm{~mm}$ and a mean temperature between $13.5^{\circ} \mathrm{C}$ and $15^{\circ} \mathrm{C}$ (Yu et al., 2017). Rapid economic development and a considerable increase in population have triggered the evident expansion of urban areas in China, including Yanzhou City was no exception. The direct results of this expansion have included a decrease in natural wetlands from 1985 to 2015 (Xiao et al., 2018). Historically, the region is characterized by agriculture, and the modern agricultural economy is concentrated on the cultivation of corn and wheat. Underground coal mining has been performed in this region for more than 40 years. The ground has been moved, deformed and even destroyed, forming a large area of underground mined-out areas, which eventually formed a large-scale subsidence. Due to the shallow groundwater and a large amount of rainwater inflow, soil paludification has formed small closedtype new wetlands of varying sizes in this region. These wetlands have a short formation time, are relatively isolated from one another, are surrounded by farmland, have no other hydrological connection, have high water alkalinity, have complex chemical composition, and have a sediment type classified as sludge. These wetlands are similar to natural shallow lakes, with water surface areas ranging from 0.59 hectares to 60.51 hectares. The main hydrological effects come from rainfall and groundwater. The wetland plants are dominated by emergent plants, such as Phragmites australis and Typha angustifolia. The main land-use pattern around the wetland is farmland. The crops are dominated by corn in summer and autumn and by wheat the rest of the year.

\section{Sampling and sample processing}

Newly formed wetlands without anthropogenic interference were the main focus in the current study, and nine wetlands with subsidence periods between 2 and 20 years were selected as targets (Fig 1). We divided the wetlands into three groups according to the history of subsidence, named IS (initial stage, 3 wetlands with a subsidence history of 2 to 5 years), MS (middle stage, 3 wetlands with a subsidence history of 9-11 years), and LS (late stage, 3 wetlands with a subsidence history of 18 to 20 years). 
135

136

137

138

139

140

141

142

143

144

145

146

147

148

149

150

151

152

153

154

155

156

157

158

159

160

161

The three subsidence time phases correspond to the three developmental stages of the new wetland:

(1) IS. In the early stage of the formation of fresh wetlands, the wetland area is small, the environment is fragile, and the water depth is shallow $(<1 \mathrm{~m})$. The wetland water volume is greatly affected by precipitation. In years with long-term drought, dryness will occur. The aquatic plants are mainly Phragmites australis and Typha angustifolia, and no fish distributions were found in the wetlands during the study period.

(2) MS. Due to the continuous subsidence of the Earth's surface, the newly developed wetland is in a dynamic and repetitive developmental stage. After nearly ten years of development, the area becomes enlarged, and the water depth increases $(1 \sim 2 \mathrm{~m})$. The main aquatic plants are Phragmites australis and Typha angustifolia, and a small amount of fish were found during the research period (e.g., Monopterus albus, Misgurnus anguillicaudatus).

(3) LS. In MSWs with a subsidence time of approximately 20 years, the subsidence process ends and the wetland area is further expanded to form a subsidence lake with a maximum depth of $5 \mathrm{~m}$. Additionally, broad coastal vegetation, composed of Phragmites australis community and Typha angustifolia community, is present. Both of these are single-species communities, reducing the diversity of vegetation composition. The surface sediment contains a large amount of organic detritus, and four fish species were found in these wetlands during the study (e.g., Monopterus albus, Misgurnus anguillicaudatus, Carassius auratus and Ctenopharyngodon idellus).

The samplings were conducted in October 2016 (autumn), January 2017 (winter), April 2017 (spring) and July 2017 (summer). Environmental variables were collected in parallel in April and July 2017 (Table 1).

\section{Macroinvertebrate sampling}

We established three sites in each MSW, with the average water depth ranging from $0.4 \mathrm{~m}$ to 1.5 $\mathrm{m}$. The bottoms of the sites were mainly characterized by sediments. Samples were collected three times from each site (collected from shallow to deep) using a 1/40 Peterson grab sampler 
162 and then combined as one sample. The total amount of sampling effort was equal at all sites. The collected samples were sorted using a $250-\mu \mathrm{m}$ pore size mesh, placed in a sealed bag, and stored in $7 \%$ buffered formalin. The collected samples were classified under the microscope and identified to the lowest possible classification unit. Mollusca and Oligochaeta were identified to species level, and taxa that could not be identified to species level (e.g., most species of Diptera, Trichoptera, Odonata and Ephemeroptera) were identified to morphospecies. The identification data used were mainly those described by Rosenberg and Resh (Rosenberg \& Resh, 1994). We summed the number of each classification unit and then used filter paper to remove the surface solution. The units were weighed on an electronic balance, and the final result was converted into density and biomass per unit area. Macrozoobenthos were collected under the field permit approval (Foundation of State Key Laboratory of Coal Mine Disaster Dynamics and Control, Chongqing University) and the project number: 2011DA105287—ZD201402.

\section{Water characteristics}

The physicochemical parameters of the surface water, including dissolved oxygen (DO), water temperature (WT), total dissolved solids (TDS), salinity (Sal), Oxidation reduction potential (ORP) and $\mathrm{pH}$, were measured using the calibrated Manta ${ }^{\mathrm{TM}} 2$ Multiparameter System (Eureka

Company, USA). A vertically integrated water sample was also collected and placed in an acidcleaned plastic container with a volume of 5 L. The total nitrogen (TN), total phosphorus (TP), and chlorophyll- $a(C h l-a)$ were measured in the laboratory according to APHA (2012).

\section{Functional feeding groups}

According to the food source and feeding mechanism (Barbour et al., 1999), macrozoobenthos were categorized into five functional feeding groups (FFGs): filter collector (FC), predator (PR), shredder ( $\mathrm{SH})$, gatherer collector (GC), and scraper (SC). In the current study, the FC group accounted for only a small proportion; therefore, the FC group was eliminated from the study.

\section{Biodiversity metrics}

We calculated the macroinvertebrate Shannon-Wiener diversity index $\left(H^{\prime}\right)$ using the Excel and Biodiversity tools. SPSS was used for statistical analysis. 
Shannon-Wiener Diversity Index $\left(H^{\prime}\right)$ :

$$
H^{\prime}=-\sum_{i=1}^{S} P i \ln P i
$$

where $P i$ is the proportion of the total sample represented by genus $(S) i$.

\section{Data analyses}

First, PERMANOVA (permutational multivariate analysis of variance) was used to determine the effects of subsidence time on the community composition of macrozoobenthos (999 permutations). The relationships between the macrozoobenthos community and the environmental factors (i.e., $\mathrm{pH}, \mathrm{TN}, \mathrm{TP}, c h l-a$, area, WT, TDS, DO, ORP and Sal) were explained by canonical correspondence analysis (CCA) (ter Braak \& Smilauer, 2002). Each environmental factor (except $\mathrm{pH})$ and the relative abundance $(\geq 1 \%)$ were converted $(\log (\mathrm{x}+1))$ before analysis. Both analyses were based on the Bray-Curtis similarity index of the relative abundance and environmental data ( $\mathrm{pH}$ excluded) after the $\log (\mathrm{x}+1)$ transformation. The rare taxa $(<1 \%)$ were removed before analysis. The significance of the influence of each environmental factor on the community composition was analyzed with a Monte Carlo test, and the contribution of the Bonferroni correction was based on the conditional effect of the CCA result.

Second, general linear models (GLMs) were used to test the subsidence time on the total richness, density, biomass, and $H^{\prime}$ of the macrozoobenthos communities, as well as on the richness and the relative abundance of the four FFGs and the major dominant taxa. Data were $\log (\mathrm{x}+1)$ transformed when they were abnormally distributed. When significant differences were identified from the GLMs, post hoc analysis was conducted for multiple comparisons by Tukey's honestly significant difference (HSD) test. Before the analyses, the richness, density, biomass and $H^{\prime}$ were averaged from three ponds and then averaged from the four sampling seasons. Additionally, the seasonal dynamics of the richness, density, biomass, and $H^{\prime}$ of the macrozoobenthos communities from the three stages were also analyzed.

\section{Results}




\section{Macrozoobenthos community composition}

216 A total of 108 samples, including 68 taxa of macrozoobenthos and 15,332 individuals, were

217 collected in the current study (Appendix). The main group was aquatic insects, including 48

218 species, followed by molluscs (14 species). Furthermore, Chironomidae dominated all the sites

219 and was the most taxonomically rich family (24 species).

220 PERMANOVA showed that the community composition of the macrozoobenthos in the

221 MSWs varied significantly with the time of subsidence $(\mathrm{F}=8.1114, P<0.001)$, significant

222

223

224

225

226

227

228

229

230

231

232

233

234

235

236

237

238

239

240

241 differences were found between IS and LS and between MS and LS $(\mathrm{F}=8.336, P<0.01 ; \mathrm{F}=9.541$, $P<0.01$, respectively), while there was no significant difference between IS and MS (F=1.602, $P>0.05)$.

In each stage of the MSWs, the main group included aquatic insects (Fig 2). Additionally, the relative abundance of aquatic insects showed a tendency to decrease as the subsidence time increased, whereas Oligochaeta exhibited the opposite tendency, i.e., its relative abundance showed a tendency to increase as the subsidence time increased. In MS, Mollusca showed a higher percentage than other stages of the MSWs.

In the IS and MS of the MSWs (Table 2), the dominant species were Chironomus plumosus, Glyptotendipes sp. and Einfeldia sp.; LS was different from IS and MS, at this stage, the dominant species were Limnodrilus hoffmeisteri, Chinonomus plumosus, and Propsilocerus akamusi.

\section{Macrozoobenthos community structure}

ANOVA showed that (Fig 3) the richness, biomass and $H^{\prime}$ of macrozoobenthos in MSWs varied significantly with the time of subsidence $(\mathrm{F}=18.478, P<0.001 ; \mathrm{F}=16.503, P<0.001$; and $\mathrm{F}=7.592, P<0.01$, respectively); all three of them were highest in MS. Significant changes in richness and $H^{\prime}$ were recorded in LS $(P<0.05)$. Significant changes in biomass were recorded only in MS $(P<0.05)$. The density was not significantly affected by the subsidence time $(\mathrm{F}=1.862, P>0.05)$, which showed a tendency to decrease as the subsidence time increased $(P>0.05)$. 
242

243

244

245

246

247

248

249

250

251

252

253

254

255

256

257

258

259

260

261

262

263

264

265

266

267

268

\section{Functioning feeding groups}

ANOVA showed (Fig 4) that the richness of $\mathrm{SH}, \mathrm{SC}$ and $\mathrm{PR}(\mathrm{F}=7.636, P<0.01 ; \mathrm{F}=17.856$, $P<0.001 ; \mathrm{F}=6.812, P<0.001$, respectively) in the MSWs varied significantly with the time of subsidence, and $\mathrm{GC}(\mathrm{F}=0.832, P>0.05)$ in the MSWs was not significantly affected by the subsidence time. The highest richness of the four FFGs was recorded in the MS, and the lowest in the LS.

The relative densities of $\mathrm{GC}, \mathrm{SH}$ and $\mathrm{SC}(\mathrm{F}=5.623, P<0.01 ; \mathrm{F}=3.325, P<0.05 ; \mathrm{F}=6.051, P<$ 0.01 , respectively) in the MSWs varied significantly with the time of subsidence, and PR $(\mathrm{F}=0.005, P>0.05)$ in the MSWs was not significantly affected by the subsidence time.

Significant changes in both GC and SH were recorded in LS $(P<0.05)$. Significant changes in SC occurred only between MS and LS, where relative densities in MS were significantly higher than those in LS.

\section{Seasonal dynamics}

The results of the GLMs (Fig 5) showed significant seasonal differences in richness, density, biomass (F=4.555, $P<0.001 ; \mathrm{F}=7.178, P<0.001$; and F=2.622, $P<0.05$, respectively), whereas there was no significant difference in $H^{\prime}(\mathrm{F}=0.882, P>0.05)$. However, the richness and density in MS and IS showed apparent seasonal variations $(P<0.05)$, which was different from the results of LS. The lowest richness and densities in IS and MS were recorded in summer. Significant changes in biomass were recorded only in MS, and the highest biomass was recorded in spring.

\section{Relationship between macrozoobenthos community and environmental factors}

The relationship between the macrozoobenthos and environmental factors in the MSWs was analyzed using $\mathrm{CCA}(\mathrm{F}=2.000, P<0.01)$ (Fig 6). The eigenvalues of the first two sorting axes in the sorted graph were 0.4227 and 0.3185 , respectively. The correlation coefficients of the first two axes with the environmental factors were 0.8543 and 0.7787 , respectively, and the environmental factors explained a total of $23.10 \%$ of the species variation information. Therefore, it can be seen that ORP, area, DO and TDS were the main environmental factors affecting macrozoobenthos in the MSWs, explaining $22.51 \%, 19.48 \%, 16.88 \%, 16.88 \%$ of the 
269

270

271

272

273

274

275

276

277

278

279

280

281

282

283

284

285

286

287

total variance, respectively.

\section{Discussion}

Some specific secondary habitats (such as MSWs) can provide enormous biodiversity conservation potential (Chester \& Robson, 2013; Harabiš et al., 2013; Harabiš, 2016). In this particular type of coal mining subsidence, we found that the developmental trajectory of the macrozoobenthos community in the MSWs was significantly affected by the time-lapse of the subsidence, which was driven by the advancement of the subsidence process. At the same time, our study also found that there was no significant difference in the macrozoobenthos community during the continuous succession period of IS and MS, indicating that the impact of subsidence time on the macrozoobenthos community was limited in a short period of time.

\section{Diversity in MSWs}

In post-mining areas, there could be high heterogeneity in secondary habitats compared with the surrounding landscapes (Tropek et al., 2010). Therefore, macrozoobenthos generally exhibit higher diversity in post-mining landscapes. For example, 35 gastropod species were found in coal mining subsidence sites in the Silesia Highlands of southern Poland (Strzelec et al., 2014); similarly, 40 odonate species were found in coal mining subsidence areas in the Czech Republic (Harabiš, 2016). Therefore, we believe that the high diversity of this habitat is not random; rather, the high diversity depends on the particular origin and environmental heterogeneity caused by subsequent succession processes, which are a direct result of mining.

The macrozoobenthos of the MSWs are composed of ubiquitous species, and most species prefer natural habitats at low altitudes. However, massive natural habitats are disappearing due to urban expansion (Mao et al., 2018; Xiao et al., 2018). Therefore, we believe that secondary habitats, such as MSWs, are another habitat for lowland (plain) species, and these habitats are similar to other secondary alternatives to natural habitats, especially in landscapes that are strongly affected by human activities (Céréghino et al., 2008; Le Viol et al., 2009; Chester \& Robson, 2013). Our research focused on the typical agricultural landscape of the North China Plain, which has relatively few natural habitats. There is only one type of similar hydrostatic 
296

297

298

299

300

301

302

303

304

305

306

307

308

309

310

311

312

313

314

315

316

317

318

319

320

321

322

water, which is often used in large volumes for fish farming. These aquaculture operations are homogeneous habitats, i.e., they have lower value for biodiversity conservation than that of MSWs. This means that the only alternatives to ponds are secondary habitats that result from coal mining activities. Therefore, we must ask: what are the factors that provide higher diversity in MSWs?

\section{Macrozoobenthos community composition and diversity changes}

Although we were unable to immediately measure the macrozoobenthos after the formation of new wetlands in coal mining subsidence areas, the rapid colonization of macrozoobenthos in the MSWs was predictable because this phenomenon is very common in newly created ponds (Ruhí et al., 2009; Thiere et al., 2009; Ishiyama et al., 2014). In fact, the newly emerged water pools in post-mining landscapes often provide particularly important refuges for species specialized for oligotrophic conditions and early-successional freshwater habitats (Dolny \& Harabis, 2012; Harabiš et al., 2013; Harabiš, 2016). Most of the increased macrozoobenthos richness was due to the immigration of active dispersers such as chironomids, beetles and dragonflies. In our study, aquatic insects accounted for more than $50 \%$ of all stages of development in newly developed wetlands, of which Chironomidae was the main component (Fig 2). This result suggests that pioneer taxa indiscriminately colonized the newly developed wetlands at different stages of development, irrespective of their environmental differences. Due to their special life history, chironomids can move and reproduce in different areas and can complete colonization early in the formation of wetlands. Chironomidae adults are effective dispersers (Batzer \& Wissinger, 1996), and they are usually the first colonizers to reach new wetlands (Barnes, 1983; Layton \& Voshell, 1991). Due to the lack of natural enemies such as fish in newly formed wetlands, the distribution of chironomid larvae showed a higher density than those of other groups. Chironomidae rapidly colonized the newly formed wetlands in the coal mining subsidence area. Most of them belonged to the GC in the FFG classification, indicating that the newly formed wetlands had sedimentary environmental conditions with fine sediment deposition and high organic content. This result is consistent with the land use (i.e., farmland) before the formation of 
323 the newly formed wetlands (Xiao et al., 2018). However, some taxa, such as Gastropoda, were

324 absent, and the presence of some taxa, such as Oligochaeta, showed low abundance, suggesting

325 they had not yet established during the IS.

326 In our study, the diversity of macrozoobenthos increased during the succession period from IS

327 to MS, while the diversity of LS was significantly lower than that of the first two stages.

328 Therefore, another question surfaced from these results: Why does the biodiversity of

329 macrozoobenthos in MSWs decrease over time? One possible explanation is that the elderly

330 wetlands had not yet been colonized by some taxa. The early colonists are usually too generalist

331 to be affected by certain habitat attributes (Jocque et al., 2010), and some specific species are

332 found in longer time segments. The subsidence history of MS is longer than that of IS, and the

333 development of habitat may allow the colonization of new species. The increase in the richness

334 of molluscs in MS may be due to the fact that, although the gastropods lack effective dispersal

335 mechanisms, some species can complete the colonization process by direct attachment to birds

336 through bird activity (Cristina et al., 2016). The lowest richness was in LS with extensive littoral

337 vegetation, which consisted of homogenous emergent plant communities (i.e., Typha angustifolia

338 community and Phragmites australis community), and constitutes a barrier to many species. This

339 finding confirms those of Harabis (Harabis, 2016), who suggested that the vegetation should be

340 kept scattered and prevented extensive overgrowth. In addition, fish may have an impact on

341 community differences, and fish are often more abundant in more mature wetlands. The

342 abundance and quantity of macrozoobenthos can be regulated because of the existence of fish,

343 e.g., Corixidae are particularly easy to subject to fish predation because they swim to the water

344 surface for fresh air (Schilling et al., 2009). Furthermore, the high relative abundance of GC in

345 the LS might have been a consequence of the surface sediments of LS being richer in organic

346 matter.

347 Seasonal dynamics

348 In our study, the macrozoobenthos communities of the IS and MS were significantly affected by

349 seasonal variation, while the community of the LS was not. This result suggested that the newer 
350

351

352

353

354

355

356

357

358

359

\section{0}

361

362

363

364

365

366

367

368

369

370

371

372

373

374

375

376

subsidence wetlands showed significantly seasonal dynamics, possibly because the ecosystem was less stable. For the LS, which had broad coastal vegetation, the area and depth of water was great enough to enhance strong adaptability to seasonal environmental variations. A change in water quantity is one major factor that affects the seasonal variation of the macrozoobenthos community (Chen et al., 2018). Because of the low rainfall in spring, the MSWs had the lowest area and shallowest water depth in spring. Pond deoxygenation and high temperature conditions, accompanied by a drastic reduction in the pond surface area and depth and high concentrations of solutes (Waterkeyn et al., 2008; Pérez-Bilbao et al., 2015), are indicative of the general impoverishment of pond environmental conditions. Rainfall generally increased during summer. This increase may have contributed to the gradual recovery of water quantity in the MSWs.

\section{Species composition and environmental variables}

The high biodiversity of water bodies is because individual ponds usually support different communities (Williams et al., 2004), even in water bodies that are close to each other, such as the MSWs in this study. The differences in the distribution of macrozoobenthos can be explained by local conditions in the wetlands (Kitagawa, 1978; Arunachalam et al., 1991; Nelson \& Lieberman, 2002; Nelson, 2011; van der Linden et al., 2012). The time of subsidence has led not only to changes in the macrozoobenthos community of the newly formed wetlands but also to the internal and external characteristics of the newly formed wetlands. The water quality of the wetlands has been shown to affect the diversity of macrozoobenthos (Lupi et al., 2013; Perissinotto et al., 2016). This is especially true for macrozoobenthos in wetlands in agricultural landscapes, where extreme changes in the parameters of the aquatic environment often occur (Meyer et al., 2015), which in turn, affect the macrozoobenthos communities.

In our study, the ORP, area, DO and TDS of water had the greatest impact on the macrozoobenthos community (Fig 6). ORP can reflect the DO status of the water, and the macrozoobenthos community varied significantly with the DO of the water (Connolly et al., 2004). If DO of the water is at a low level, DO can become a limiting factor for macrozoobenthos in the habitat (Martien \& Benke, 1977; Beisel et al., 2000; Allan \& Castillo, 
377

378

379

380

381

382

383

384

385

386

2007). For instance, in our study, Polypedilum sp. increased with increasing DO of the water, while Bellamya purificata was negatively related to the DO of the water (Fig 6), showing their ability to tolerate and thrive in this type of water environment (Ocon et al., 2008). The water area of the same coal mining subsidence area will gradually expand with the subsidence time. The area of the wetland has been shown to have a significant impact on the diversity and richness of the taxa (Studinski \& Grubbs, 2007). For example, in our study, Limnodrilus hoffmeisteri increased with increasing water area, while Gyraulus convexiusculus and Tanytarsus sp. were negatively related to the water area. This relationship for Gyraulus convexiusculus and Tanytarsus sp. might help explain their decline during LS, as the water area increased over this period (Fig 6). Moreover, the area of the pond can affect the temperature of the water as well as the interaction between competition and predation (Pearman, 1994). TDS, which is a mixture of salts (e.g. magnesium, sodium, calcium, potassium, chlorides, bicarbonates and sulphates), organic matter and other dissolved materials in water (Weber-Scannell \& Duffy, 2007). In our study, an increase of TDS affected most species negatively (Fig 6), confirming the findings of many studies (Ndaruga et al., 2004; Timpano et al., 2015; Mwedzi et al., 2016). TDS also causes toxicity through increases in salinity, changes in the ionic composition of the water and toxicity of individual ions (Weber-Scannell \& Duffy, 2007).

\section{CONCLUSIONS}

We found that the macrozoobenthos community in the newly formed wetlands showed high diversity, and the developmental trajectory of the macrozoobenthos community was significantly affected by the time-lapse of the subsidence, showing the continuous succession of the diversity of the newly formed wetland during an intermediate time period. The stage is the highest and then gradually decreases. We believe that in the early stages of newly formed wetlands, the diversity of the macrozoobenthos community is mainly related to the life history and migration ability of animals. As time proceeds, the changes in the environmental factors gradually play a role, and these changes are mainly driven by the subsidence time. 
404

405

406

407

408

409

410

411

412

413

414

415

416

417

418

419

420

421

422

423

424

425

426

427

428

429

430

431

432

433

434

435

436

The drastic changes in the surface structure caused by the subsidence of coal mining have placed enormous pressure on both the ecosystem and the environment. However, our findings have challenged the original understanding of coal mining subsidence. We believe that we can see not only some secondary geological disasters that may occur in coal mining subsidence but also ecological opportunities introduced by the formation of new wetlands in coal mining subsidence areas. The new habitats in post-mining areas signify the diversity of (micro-) habitats across a broad spectrum of succession stages. These special secondary habitats have been strengthened due to the decreasing natural habitats. Therefore, secondary habitat geography should be an integral part of nature conservation. We should not only protect secondary habitats but also protect their continuous succession process.

\section{Acknowledgements}

The authors thank Fengyue Shu, Chenglong Ma, Yuehuan Dong, Jingtai Li, Guangshuo Han, Mengjie Zhang, Lilei Zhou, Shuaikai Wu, Kuo Sun, Yuxing Hu and Guofeng Yang for field assistance.

\section{REFERENCES}

Allan JD, and Castillo MM. 2007. Stream ecology: Structure and function of running waters: Second edition. Springer Netherlands.DOI:10.1007/978-1-4020-5583-6

Arunachalam M, Madhusoodanan Nair KC, Vijverberg J, Kortmulder K, and Suriyanarayanan H. 1991. Substrate selection and seasonal variation in densities of invertebrates in stream pools of a tropical river. Hydrobiologia 213:141-148.DOI:10.1007/bf00015000

Baasch A, Kirmer A, and Tischew S. 2012. Nine years of vegetation development in a postmining site: effects of spontaneous and assisted site recovery. Journal Of Applied Ecology 49:251-260.DOI:10.1111/j.13652664.2011.02086.x

Ball-Damerow JE, M'Gonigle LK, and Resh VH. 2014. Changes in occurrence, richness, and biological traits of dragonflies and damselflies (Odonata) in California and Nevada over the past century. Biodiversity And Conservation 23:2107-2126.DOI:10.1007/s10531-014-0707-5

Barbour MT, Gerritsen J, Snyder BD, and Stribling JB. 1999. Rapid bioassessment protocols foruse in streams and wadable rivers: Periphyton, benthic invertebrates and fish.

Barnes LE. 1983. The colonization of ball-clay ponds by macroinvertebrates and macrophytes. Freshwater Biology 13:561-578.DOI:10.1111/j.1365-2427.1983.tb00013.x

Batzer DP, and Wissinger SA. 1996. Ecology of Insect Communities in Nontidal Wetlands. Annual Review of Entomology 41:75-100.DOI:10.1146/annurev.en.41.010196.000451

Beisel J-N, Usseglio-Polatera P, and Moreteau J-C. 2000. The spatial heterogeneity of a river bottom: a key factor 
437

438

439

440

441

442

443

444

445

446

447

448

449

450

451

452

453

454

455

456

457

458

459

460

461

462

463

464

465

466

467

468

469

470

471

472

473

474

475

476

477

determining macroinvertebrate communities. Hydrobiologia 422:163-171.DOI:10.1023/a:1017094606335

Benes J, Kepka P, and Konvicka M. 2003. Limestone quarries as refuges for European xerophilous butterflies. Conservation Biology 17:1058-1069.DOI:10.1046/j.1523-1739.2003.02092.x

Burgmer T, Hillebrand H, and Pfenninger M. 2007. Effects of climate-driven temperature changes on the diversity of freshwater macroinvertebrates. Oecologia 151:93-103.DOI:10.1007/s00442-006-0542-9

Céréghino R, Ruggiero A, Marty P, and Angélibert S. 2008. Biodiversity and distribution patterns of freshwater invertebrates in farm ponds of a south-western French agricultural landscape. Hydrobiologia 597:4351.DOI:10.1007/s10750-007-9219-6

Chang F-H, Lawrence JE, Rios-Touma B, and Resh VH. 2014. Tolerance values of benthic macroinvertebrates for stream biomonitoring: assessment of assumptions underlying scoring systems worldwide. Environmental Monitoring and Assessment 186:2135-2149.DOI:10.1007/s10661-013-3523-6

Chen J, Hu D, Zhang C, and Ding Z. 2018. Temporal and spatial changes of macrobenthos community in the regions frequently occurring black water aggregation in Lake Taihu. Sci Rep 8:5712.DOI:10.1038/s41598018-24058-y

Chester ET, and Robson BJ. 2013. Anthropogenic refuges for freshwater biodiversity: Their ecological characteristics and management. Biological Conservation 166:64-75.DOI:10.1016/j.biocon.2013.06.016

Christman VD, and Voshell JR. 1993. Changes in the benthic macroinvertebrate community in 2 years of colonization of new experimental ponds. Internationale Revue Der Gesamten Hydrobiologie 78:481491.DOI:10.1002/iroh.19930780403

Connolly NM, Crossland MR, and Pearson RG. 2004. Effect of low dissolved oxygen on survival, emergence, and drift of tropical stream macroinvertebrates. Journal Of the North American Benthological Society 23:251270.DOI:10.1899/0887-3593(2004)023<0251:eoldoo $>2.0 . c 0 ; 2$

Cristina C, Bram V, Luc B, Luz B, and J. GA. 2016. Newly created ponds complement natural waterbodies for restoration of macroinvertebrate assemblages. Freshwater Biology 61:16401654.DOI:doi:10.1111/fwb.12804

Dolny A, and Harabis F. 2012. Underground mining can contribute to freshwater biodiversity conservation: Allogenic succession forms suitable habitats for dragonflies. Biological Conservation 145:109117.DOI:10.1016/j.biocon.2011.10.020

Hölker F, Vanni MJ, Kuiper JJ, Meile C, Grossart H-P, Stief P, Adrian R, Lorke A, Dellwig O, Brand A, Hupfer M, Mooij WM, Nützmann G, and Lewandowski J. 2015. Tube-dwelling invertebrates: tiny ecosystem engineers have large effects in lake ecosystems. Ecological Monographs 85:333-351.DOI:doi:10.1890/141160.1

Harabis F. 2016. High diversity of odonates in post-mining areas: Meta-analysis uncovers potential pitfalls associated with the formation and management of valuable habitats. Ecological Engineering 90:438446.DOI:10.1016/j.ecoleng.2016.01.070

Harabiš F. 2016. High diversity of odonates in post-mining areas: Meta-analysis uncovers potential pitfalls associated with the formation and management of valuable habitats. Ecological Engineering 90:438446.DOI:10.1016/j.ecoleng.2016.01.070

Harabis F, and Dolny A. 2015. Odonates need natural disturbances: how human-induced dynamics affect the diversity of dragonfly assemblages. Freshwater Science 34:1050-1057.DOI:10.1086/682234

Harabiš F, Tichanek F, and Tropek R. 2013. Dragonflies of freshwater pools in lignite spoil heaps: Restoration 
management, habitat structure and conservation value. Ecological Engineering 55:5161.DOI:10.1016/j.ecoleng.2013.02.007

Hendrychová M, Šálek M, Tajovský K, and Řehoř M. 2012. Soil Properties and Species Richness of Invertebrates on Afforested Sites after Brown Coal Mining. Restoration Ecology 20:561-567.DOI:doi:10.1111/j.1526100X.2011.00841.X

Hong HN, Everaert G, Gabriels W, Hoang TH, and Goethals PLM. 2014. A multimetric macroinvertebrate index for assessing the water quality of the Cau river basin in Vietnam. Limnologica 45:1623.DOI:10.1016/j.limno.2013.10.001

Hu Z, and Xiao W. 2013. Optimization of concurrent mining and reclamation plans for single coal seam: a case study in northern Anhui, China. Environmental Earth Sciences 68:1247-1254.DOI:10.1007/s12665-012$1822-9$

Irons JG, Oswood MW, and Bryant JP. 1988. Consumption of leaf detritus by a stream shredder: Influence of tree species and nutrient status. Hydrobiologia 160:53-61.DOI:10.1007/bf00014278

Ishiyama N, Akasaka T, and Nakamura F. 2014. Mobility-dependent response of aquatic animal species richness to a wetland network in an agricultural landscape. Aquatic Sciences 76:437-449.DOI:10.1007/s00027-0140345-8

Janse JH, Scheffer M, Lijklema L, Van Liere L, Sloot JS, and Mooij WM. 2010. Estimating the critical phosphorus loading of shallow lakes with the ecosystem model PCLake: Sensitivity, calibration and uncertainty. Ecological Modelling 221:654-665.DOI:10.1016/j.ecolmodel.2009.07.023

Jocque M, Vanschoenwinkel B, and Brendonck LUC. 2010. Freshwater rock pools: a review of habitat characteristics, faunal diversity and conservation value. Freshwater Biology.DOI:10.1111/j.13652427.2010.02402.x

Kappes H, and Haase P. 2012. Slow, but steady: dispersal of freshwater molluscs. Aquatic Sciences 74:114.DOI:10.1007/s00027-011-0187-6

Kitagawa N. 1978. A Classification of Japanese Lakes based on Hypolimnetic Oxygen and Benthonic Fauna. Japanese Journal of Limnology 39:1-8.DOI:10.3739/rikusui.39.1

Layton RJ, and Voshell JJR. 1991. Colonization of New Experimental Ponds by Benthic Macroinvertebrates. Environmental Entomology 20:110-117.DOI:10.1093/ee/20.1.110

Le Viol I, Mocq J, Julliard R, and Kerbiriou C. 2009. The contribution of motorway stormwater retention ponds to the biodiversity of aquatic macroinvertebrates. Biological Conservation 142:31633171.DOI:10.1016/j.biocon.2009.08.018

Lubertazzi MA, and Ginsberg HS. 2009. Persistence of Dragonfly Exuviae on Vegetation and Rock Substrates. Northeastern Naturalist 16:141-147.DOI:10.1656/045.016.0112

Lupi D, Rocco A, and Rossaro B. 2013. Benthic macroinvertebrates in Italian rice fields. Journal of Limnology 72:184-200.DOI:10.4081/jlimnol.2013.e15

Mao D, Wang Z, Wu J, Wu B, Zeng Y, Song K, Yi K, and Luo L. 2018. China's wetlands loss to urban expansion. Land Degradation \& Development 29:2644-2657.DOI:doi:10.1002/ldr.2939

Martien RF, and Benke AC. 1977. Distribution and Production of Two Crustaceans in a Wetland Pond. American Midland Naturalist 98:162-175.DOI:10.2307/2424722

Mereta ST, Boets P, De Meester L, and Goethals PLM. 2013. Development of a multimetric index based on benthic macroinvertebrates for the assessment of natural wetlands in Southwest Ethiopia. Ecological Indicators 
29:510-521.DOI:10.1016/j.ecolind.2013.01.026

Meyer MD, Davis CA, and Dvorett D. 2015. Response of Wetland Invertebrate Communities to Local and Landscape Factors in North Central Oklahoma. Wetlands 35:533-546.DOI:10.1007/s13157-015-0642-6

Mwedzi T, Bere T, and Mangadze T. 2016. Macroinvertebrate assemblages in agricultural, mining, and urban tropical streams: implications for conservation and management. Environmental Science and Pollution Research 23:11181-11192.DOI:10.1007/s11356-016-6340-y

Ndaruga AM, Ndiritu GG, Gichuki NN, and Wamicha WN. 2004. Impact of water quality on macroinvertebrate assemblages along a tropical stream in Kenya. African Journal of Ecology 42:208216.DOI:10.1111/j.1365-2028.2004.00516.x

Nelson SM. 2011. Response of stream macroinvertebrate assemblages to erosion control structures in a wastewater dominated urban stream in the southwestern U.S. Hydrobiologia 663:51-69.DOI:10.1007/s10750-0100550-y

Nelson SM, and Lieberman DM. 2002. The influence of flow and other environmental factors on benthic invertebrates in the Sacramento River, U.S.A. Hydrobiologia 489:117-129.DOI:10.1023/a:1023268417851

Ocon CS, Rodrigues Capitulo A, and Paggi AC. 2008. Evaluation of zoobenthic assemblages and recovery following petroleum spill in a coastal area of Rio de la Plata estuarine system, South America. Environmental Pollution 156:82-89.DOI:10.1016/j.envpol.2007.12.035

Pérez-Bilbao A, Benetti CJ, and Garrido J. 2015. Assessment of the effects of the dry period on the faunal composition of aquatic macroinvertebrate assemblages in two temporary ponds in NW Spain. Journal of Limnology.DOI:10.4081/jlimnol.2015.1060

Pearman A. 1994. The Use of Stated Preference Methods in the Evaluation of Environmental Change. In: Pethig R, ed. Valuing the Environment: Methodological and Measurement Issues. Dordrecht: Springer Netherlands, 229-249.

Perissinotto R, Bird MS, and Bilton DT. 2016. Predaceous water beetles (Coleoptera, Hydradephaga) of the Lake St Lucia system, South Africa: biodiversity, community ecology and conservation implications. Zookeys:85135.DOI:10.3897/zookeys.595.8614

Podgorska M. 2015. Specific remnants of old iron-ore extraction sites as islands of plant species richness. Open Life Sciences 10:182-194.DOI:10.1515/biol-2015-0023

Prach K, and Pyšek P. 2001. Using spontaneous succession for restoration of human-disturbed habitats: Experience from Central Europe. Ecological Engineering 17:55-62.DOI:10.1016/S0925-8574(00)00132-4

Rosenberg DM, and Resh VH. 1994. Freshwater Biomonitoring and Benthic Macro-Invertebrates.h. The Quarterly Review of Biology 69:286-287.DOI:10.1086/418598

Ruhí A, Boix D, Sala J, Gascón S, and Quintana XD. 2009. Spatial and temporal patterns of pioneer macrofauna in recently created ponds: taxonomic and functional approaches. Hydrobiologia 634:137151.DOI:10.1007/s10750-009-9896-4

Samways MJ. 1989. Farm dams as nature reserves for dragonflies (Odonata) at various altitudes in the Natal Drakensberg Mountains, South Africa. Biological Conservation 48:181-187.DOI:10.1016/00063207(89)90117-1

Schilling EG, Loftin CS, and Huryn AD. 2009. Macroinvertebrates as indicators of fish absence in naturally fishless lakes. Freshwater Biology 54:181-202.DOI:10.1111/j.1365-2427.2008.02096.x

Solimini AG, Ruggiero A, Bernardini V, and Carchini G. 2003. Temporal pattern of macroinvertebrate diversity and 
production in a new man made shallow lake. Hydrobiologia 506:373379.DOI:10.1023/B:HYDR.0000008548.59202.bb

Strzelec M, Krodkiewska M, and Krolczyk A. 2014. The impact of environmental factors on the diversity of gastropod communities in sinkhole ponds in a coal mining region (Silesian Upland, Southern Poland). Biologia 69:780-789.DOI:10.2478/s11756-014-0369-5

Studinski JM, and Grubbs SA. 2007. Environmental factors affecting the distribution of aquatic invertebrates in temporary ponds in Mammoth Cave National Park, Kentucky, USA. Hydrobiologia 575:211220.DOI:10.1007/s10750-006-0368-9

Suding KN, Gross KL, and Houseman GR. 2004. Alternative states and positive feedbacks in restoration ecology. Trends Ecol Evol 19:46-53.DOI:10.1016/j.tree.2003.10.005

ter Braak, and Smilauer PN. 2002. Canoco reference manual and CanoDraw for Windows user"s guide: software for canonical community ord. Ithaca $N y U_{s a} W w w$

Thiere G, Milenkovski S, Lindgren P-E, Sahlén G, Berglund O, and Weisner SEB. 2009. Wetland creation in agricultural landscapes: Biodiversity benefits on local and regional scales. Biological Conservation 142:964-973.DOI:10.1016/j.biocon.2009.01.006

Timpano AJ, Schoenholtz SH, Soucek DJ, and Zipper CE. 2015. Salinity as a Limiting Factor for Biological Condition in Mining-Influenced Central Appalachian Headwater Streams. Journal of the American Water Resources Association 51:240-250.DOI:10.1111/jawr.12247

Tropek R, Kadlec T, Karesova P, Spitzer L, Kocarek P, Malenovsky I, Banar P, Tuf IH, Hejda M, and Konvicka M. 2010. Spontaneous succession in limestone quarries as an effective restoration tool for endangered arthropods and plants. Journal Of Applied Ecology 47:139-147.DOI:10.1111/j.1365-2664.2009.01746.x

van der Linden P, Patrício J, Marchini A, Cid N, Neto JM, and Marques JC. 2012. A biological trait approach to assess the functional composition of subtidal benthic communities in an estuarine ecosystem. Ecological Indicators 20:121-133.DOI:10.1016/j.ecolind.2012.02.004

Vander Zanden MJ, and Gratton C. 2011. Blowin' in the wind: reciprocal airborne carbon fluxes between lakes and land This paper is based on the J.C. Stevenson Memorial Lecture presented at the Canadian Conference for Fisheries Research (CCFFR) in Ottawa, Ontario, 9-11 January 2009. Canadian Journal of Fisheries and Aquatic Sciences 68:170-182.DOI:10.1139/F10-157

Villnäs A, and Norkko A. 2011. Benthic diversity gradients and shifting baselines: implications for assessing environmental status. Ecological Applications 21:2172-2186.DOI:doi:10.1890/10-1473.1

Waterkeyn A, Grillas P, Vanschoenwinkel B, and Brendonck L. 2008. Invertebrate community patterns in Mediterranean temporary wetlands along hydroperiod and salinity gradients. Freshwater Biology 53:18081822.DOI:doi:10.1111/j.1365-2427.2008.02005.x

Weber-Scannell PK, and Duffy LK. 2007. Effects of Total Dissolved Solids on Aquatic Organisms: A Review of Literature and Recommendation for Salmonid Species. American Journal of Environmental Sciences 3:16.DOI:10.3844/ajessp.2007.1.6

Williams P, Whitfield M, Biggs J, Bray S, Fox G, Nicolet P, and Sear D. 2004. Comparative biodiversity of rivers, streams, ditches and ponds in an agricultural landscape in Southern England. Biological Conservation 115:329-341.DOI:10.1016/s0006-3207(03)00153-8

Xiao W, Fu Y, Wang T, and Lv X. 2018. Effects of land use transitions due to underground coal mining on ecosystem services in high groundwater table areas: A case study in the Yanzhou coalfield. Land Use 
Policy 71:213-221.DOI:10.1016/j.landusepol.2017.11.059

602

Yu Z, Wang H, Meng J, Miao M, Kong Q, Wang R, and Liu J. 2017. Quantifying the responses of biological indices to rare macroinvertebrate taxa exclusion: Does excluding more rare taxa cause more error? Ecol Evol 7:1583-1591.DOI:10.1002/ece3.2798

Zeng F, Wu K, He Q, Diao X, and Li L. 2016. Model Establishment for Ponding in Coal Mining Subsidence Areas and its Prediction: Case Study of Northern Jining, China. Geotechnical and Geological Engineering 35:8389.DOI:10.1007/s10706-016-0086-7

608

\section{Appendix}

610 The species list of macrozoobenthos of three stages of mining subsidence wetlands

\begin{tabular}{|c|c|c|c|}
\hline Taxa & Initial stage & Middle stage & Late stage \\
\hline \multicolumn{4}{|l|}{ Nematoda } \\
\hline Nematodae sp. & 3 & & 16 \\
\hline \multicolumn{4}{|l|}{ Annelida } \\
\hline \multicolumn{4}{|l|}{ Oligochaeta } \\
\hline Limnodrilus hoffmeisteri & 17 & 103 & 1188 \\
\hline Branchiura sowerbyi & 36 & 176 & 24 \\
\hline \multicolumn{4}{|l|}{ Hirudinea } \\
\hline Glossiphonia lata & & 1 & 1 \\
\hline Whitmania pigra & 4 & 2 & 3 \\
\hline \multicolumn{4}{|l|}{ Mollusca } \\
\hline \multicolumn{4}{|l|}{ Gastropoda } \\
\hline Cipangopaludina chinensis & & 4 & \\
\hline Bellamya purificata & & 15 & 2 \\
\hline Gyraulus convexiusculus & 8 & 131 & \\
\hline Gyraulus compressus & 5 & 140 & \\
\hline Parafossarulus striatulus & & 19 & 1 \\
\hline Physa acuta & 58 & 85 & \\
\hline Radix lagotis & 123 & 315 & 2 \\
\hline Radix swinhoei & 4 & & 1 \\
\hline Galba pervia & 16 & 35 & \\
\hline Galba turncatula & & 2 & \\
\hline Alocinma longicornis & & 1 & 1 \\
\hline Polypylis hemisphaerula & & 6 & \\
\hline Hippeutis cantori & 52 & 105 & \\
\hline Hippeutis umbilicalis & 5 & 24 & \\
\hline \multicolumn{4}{|l|}{ Arthropoda } \\
\hline \multicolumn{4}{|l|}{ Insecta } \\
\hline Diptera & & & \\
\hline
\end{tabular}


Chironomus plumosus

Hydrobaenus sp.

Stictochironomus sp.

Einfeldia sp.

Dicrotendipes sp.

Orthocladius sp.

Psectrocladius sp.

Paratendipes sp.

Chaetocladius sp.

Cladopelma sp.

Diamesa $\mathrm{sp.}$

Tvetenia $\mathrm{sp}$.

Propsilocerusi sp.

Chironmidae sp.

Tanytarsus sp.

Glyptotendipes sp.

Cricotopus sp.

Endochironomus sp.

Polypedilum sp.

Cryptochironomus sp.

Clinotanypus sp.

Procladius sp.

Ablabesmyia sp.

Tanypus sp.

Culicoides sp.

Musca domestica

Tipulidae sp.

\section{Coleoptera}

Hydrophilidae sp.

Cybister chinensis

Laccophilus difficilis

Heterocerus sauteri

Chlaenius sp.

Carabidae sp.

\section{Trichoptera}

Phryganea sp1.

Phryganea sp2.

Odonata

Gomphus sp.

Anax sp.

Aeshna sp. 
Anisogomphus sp.

Libellula sp.

Cercion sp.

Lestes sp.

Ischnura Iabata

Aciagrion hisopa

\section{Ephemeroptera}

Baetis sp.

Siphlonurus sp.

\section{Hemiptera}

Diplonychus esakii

Corixidae sp.

Crustacea

Decapoda
8

5

61

14

3

45
101

1

611 


\section{Table 1 (on next page)}

Environmental variables describing the study sites. 


\begin{tabular}{|c|c|c|c|c|}
\hline \multirow[t]{2}{*}{ Environmental variables } & \multicolumn{3}{|c|}{ Min-Max (Mean) } & \multirow[t]{2}{*}{ Units } \\
\hline & Initial stage & Middle stage & Late stage & \\
\hline Subsidence history & $3 \sim 5(5)$ & $9 \sim 11(10)$ & 18 20(19) & year \\
\hline Water area & $3.09 \sim 30.17(5.82)$ & $1.84 \sim 11.85(6.88)$ & $32.86 \sim 60.51(50.63)$ & ha. \\
\hline Water depth & $0.3 \sim 0.7(0.5)$ & $0.3 \sim 1(0.6)$ & $0.4 \sim 1.8(0.8)$ & $\mathrm{m}$ \\
\hline Water temperature & $18.66 \sim 30.78(27.08)$ & $20.49 \sim 29.38(26.42)$ & $20.9 \sim 31.73(27.94)$ & ${ }^{\circ} \mathrm{C}$ \\
\hline Chlorophyll- $a$ & $1.09 \sim 30.17(5.82)$ & $0.55 \sim 41.50(6.55)$ & $0.55 \sim 134.86(18.29)$ & $\mu \mathrm{g}^{-1}$ \\
\hline Total dissolved solids & $6.29 \sim 15.78(12.26)$ & $5.10 \sim 12.45(9.20)$ & $11.10 \sim 14.51(12.60)$ & $\mathrm{g} \mathrm{l}^{-1}$ \\
\hline Salinity & $5.42 \sim 14.78(11.18)$ & $4.33 \sim 11.91(8.18)$ & $9.96 \sim 13.41(11.50)$ & $\%$ \\
\hline Dissolved oxygen & $0.75 \sim 12.48(5.59)$ & $0.13 \sim 14.03(3.74)$ & $3.25 \sim 11.94(7.01)$ & $\mathrm{mg} \mathrm{l}^{-1}$ \\
\hline $\mathrm{pH}$ & $6.17 \sim 8.66(7.75)$ & $5.50 \sim 7.46(6.99)$ & $6.03 \sim 9.53(8.16)$ & - \\
\hline Oxidation reduction potential & $39.6 \sim 288.3(127.0)$ & $13.6 \sim 265.3(148.2)$ & $90.7 \sim 300.7(182.6)$ & $\mathrm{mV}$ \\
\hline Total phosphorus & $0.42 \sim 0.63(0.18)$ & $0.09 \sim 0.52(0.13)$ & $0.08 \sim 0.52(0.15)$ & $\mathrm{mg} \mathrm{l}^{-1}$ \\
\hline Total nitrogen & $0.82 \sim 2.13(1.52)$ & $0.70 \sim 2.41(1.14)$ & $0.90 \sim 2.41(1.45)$ & $\mathrm{mg} \mathrm{l}^{-1}$ \\
\hline
\end{tabular}

2 
Table 2 (on next page)

The dominant species of the three stages of the mining subsidence wetlands 
Subsidence history Dominant species (relative abundance)

Initial stage $\quad$ Chironomus plumosus (35.80\%), Glyptotendipes sp. (34.50\%), Einfeldia sp. (11.32\%)
Middle stage $\quad$ Glyptotendipes sp. $(36.83 \%)$, Chironomus plumosus $(17.86 \%)$, Einfeldia sp. $(6.94 \%)$
Late stage
Limnodrilus hoffmeisteri (39.35\%), Chinonomus plumosus (24.18\%), Propsilocerus akamusi (14.11\%)

1 


\section{Figure 1}

The map shows study area is located in Shandong Province, China, and ( $A, E, F)$ shows the initial stage of mining subsidence wetlands (MSWs), and $(G, H, I)$ show middle stage of MSWs, the remaining photographs depict $(B, C, D)$ late stage of MSWs.

Photo credits: Guanxiong Zhang

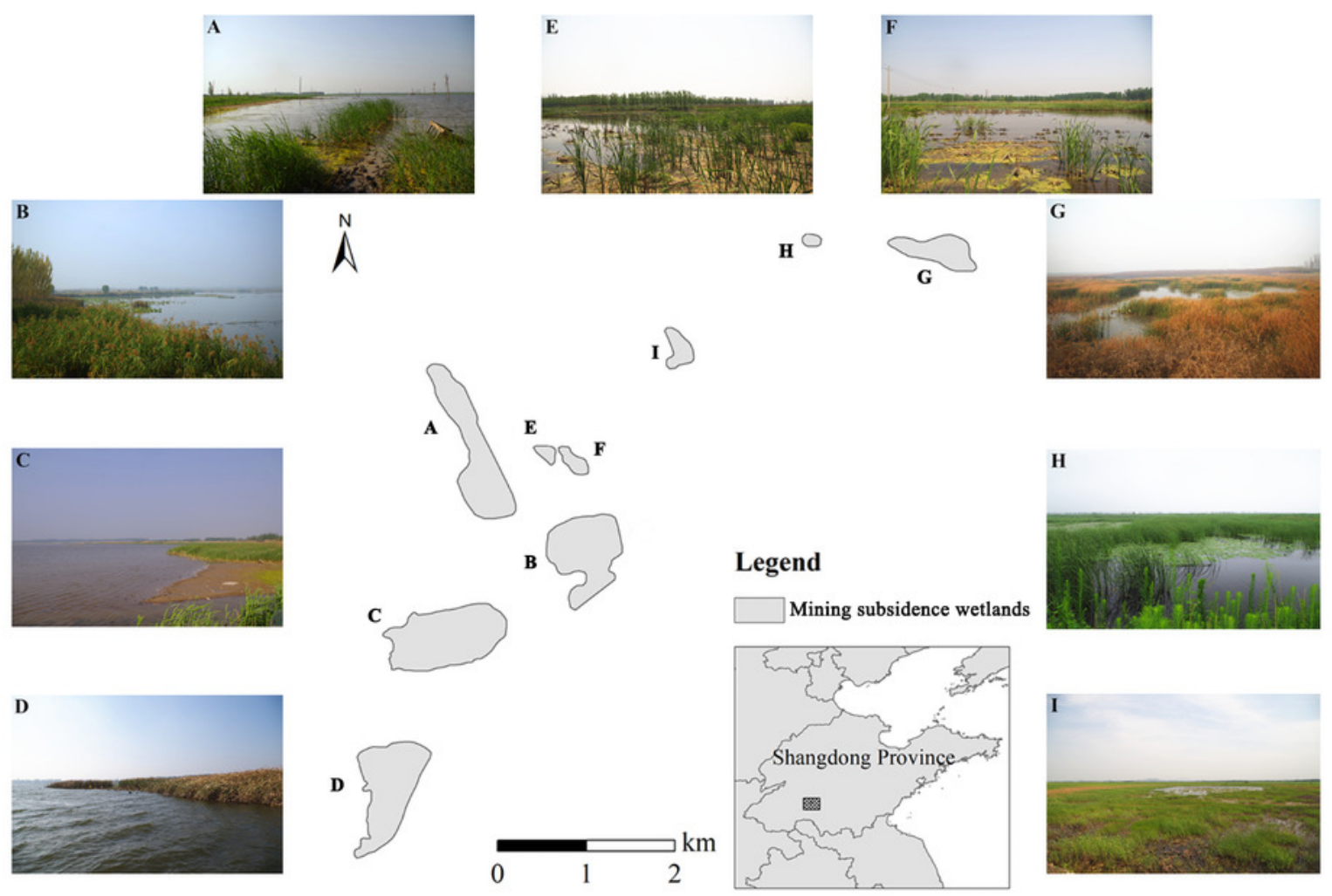




\section{Figure 2}

Mean the community composition of the macrozoobenthos of each stage in mining subsidence wetlands.

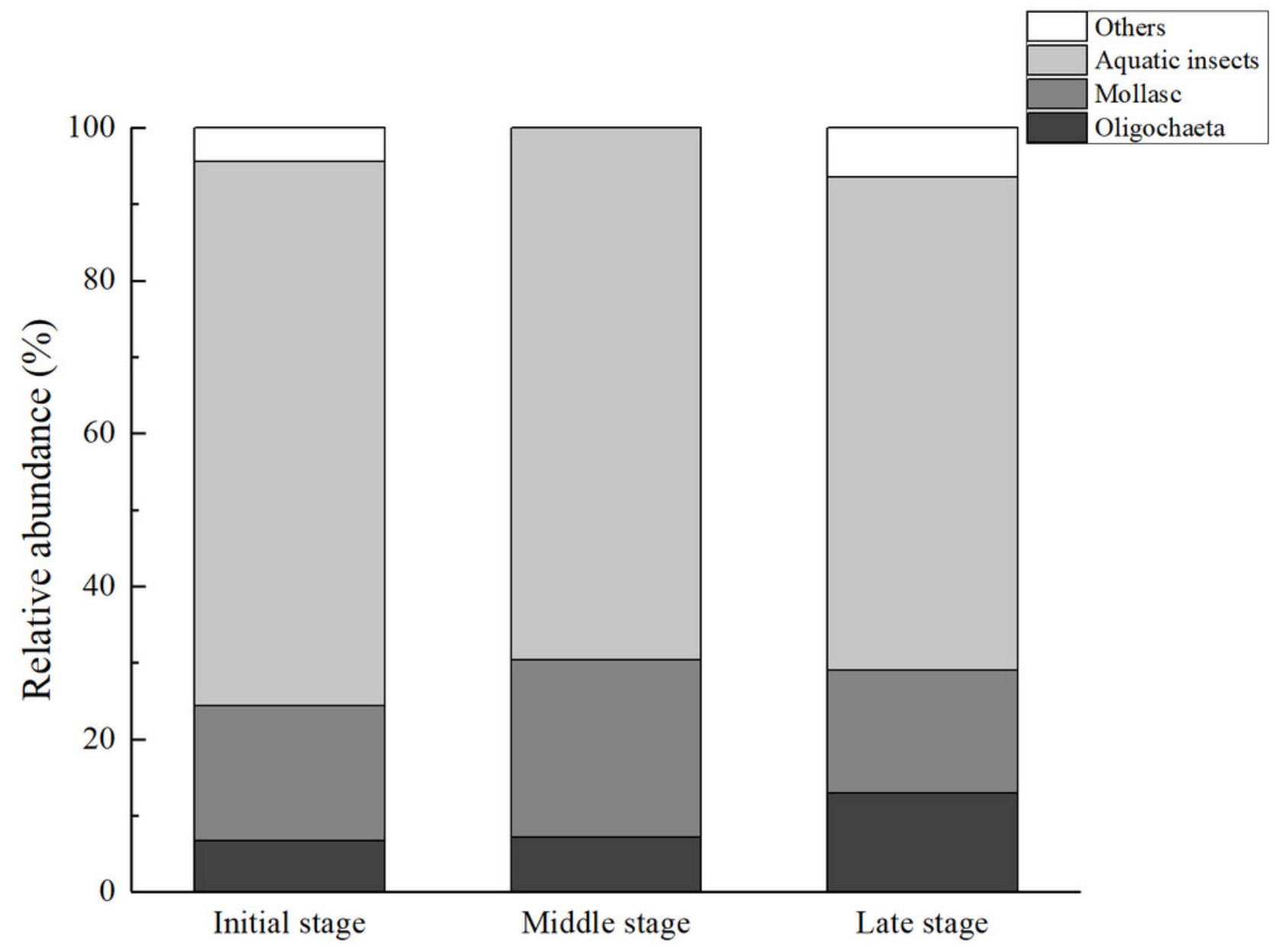


Figure 3

Mean species richness (A), density (B), biomass (C) and Shannon-Wiener index (D) of macrozoobenthos of each stage in mining subsidence wetlands.

Standard error is represented by the vertical bars. Different letters represent significant differences in macrozoobenthos communites based on Tukey HSD test.
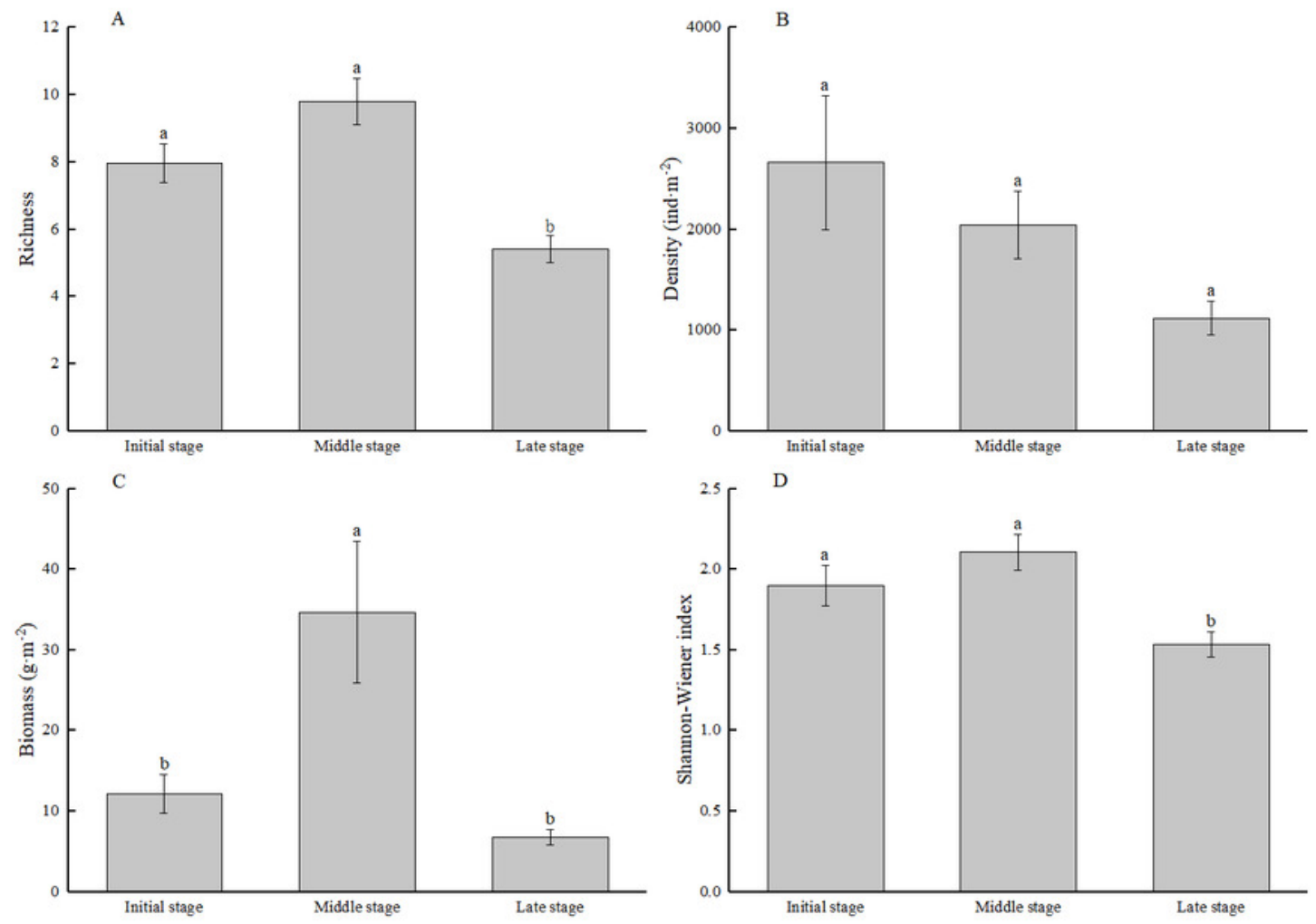


\section{Figure 4}

Mean species relative density (A) and richness (B) of functional feeding groups (FFGs) of macrozoobenthos of each stage in mining subsidence wetlands.

Standard error is represented by the vertical bars. Different letters represent significant differences in macrozoobenthos communites based on Tukey HSD test.

Abbreviations: GC (gatherer collector), SH (shredder), SC (scraper), PR (predator)
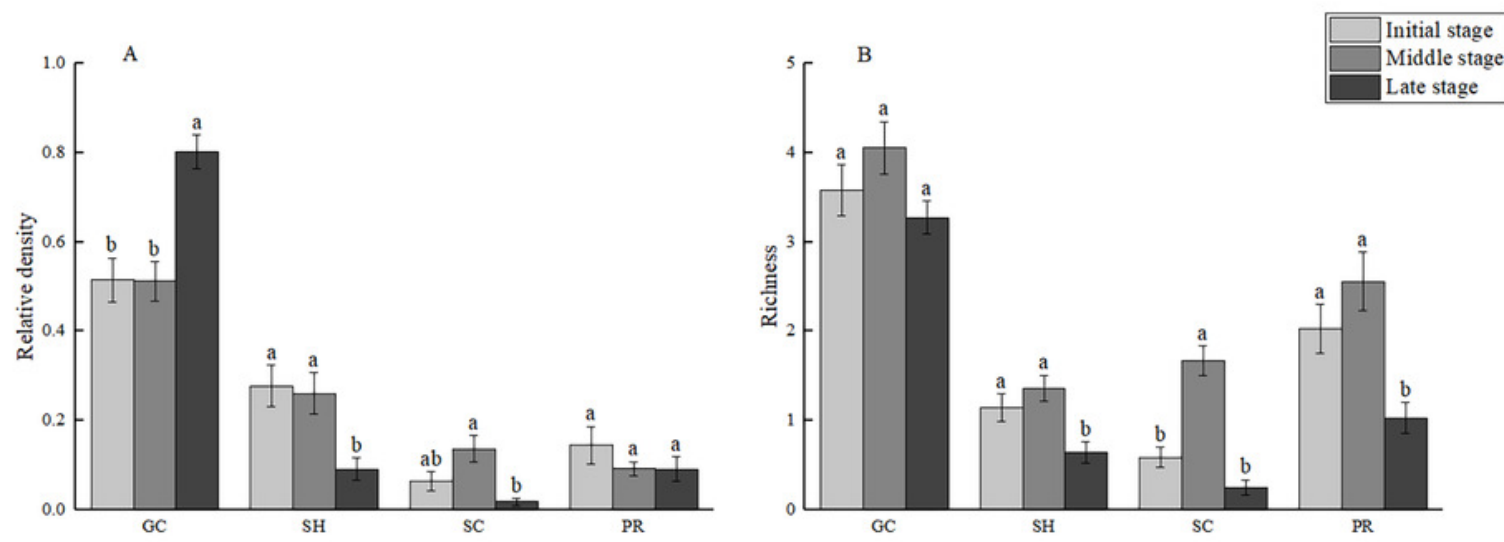
Figure 5

Mean species richness (A), density (B), Shannon-wiener index (C) and biomass (D) of each stage in mining subsidence wetlands during the four seasons of collection.

Standard error is represented by the vertical bars. Different letters represent significant differences in macrozoobenthos communites during the four seasons of collection based on Tukey HSD test.
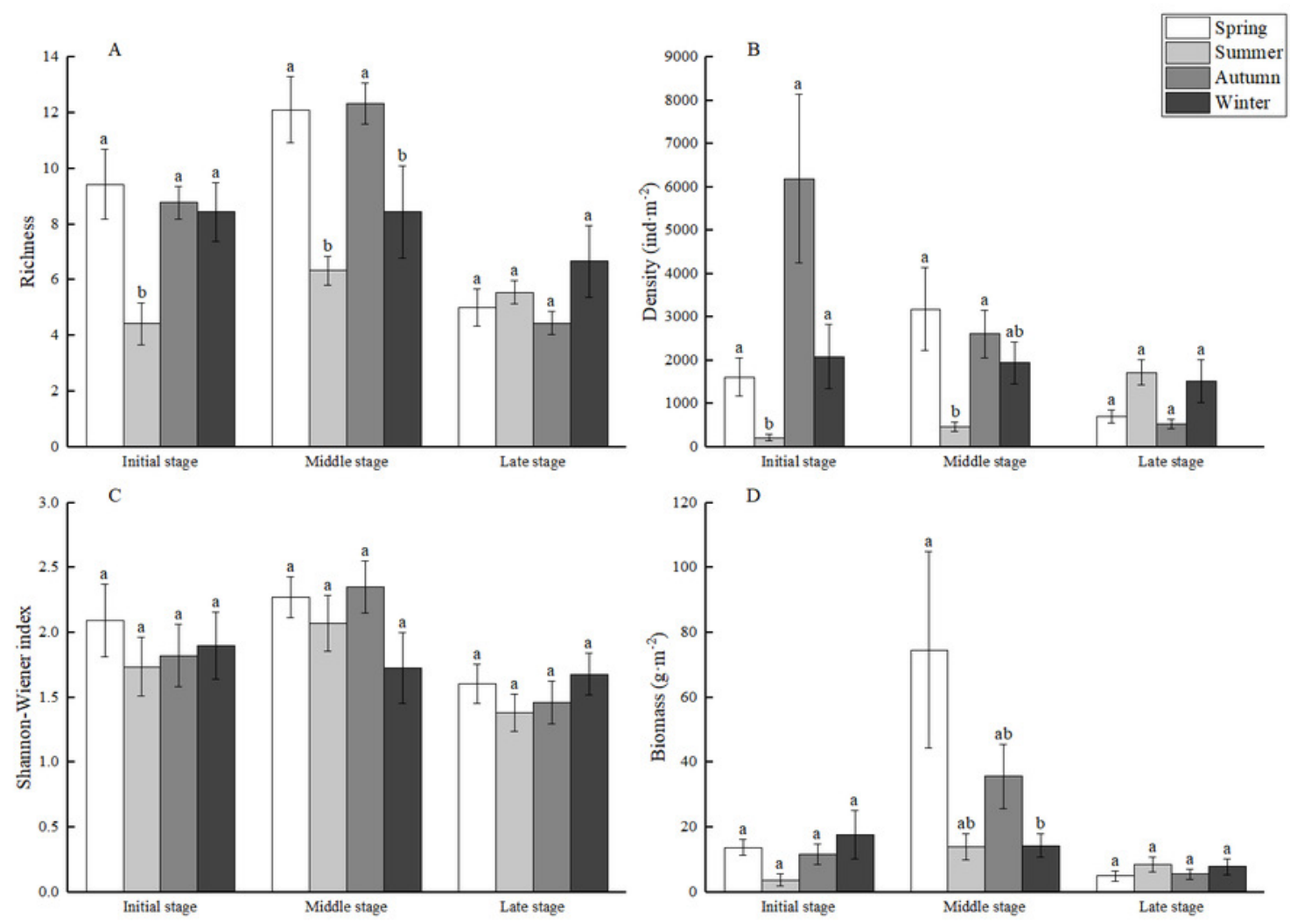


\section{Figure 6}

\section{Canonical correspondence analysis (CCA) ordinationdepicting relationships among abundances of macrozoobenthos and environmentalvariables.}

Macrozoobenthos abbreviations: Ah (Aciagrion hisopa), Bp (Bellamya purificata), Bs (Branchiura sowerbyi), Bs2 (Baetis sp.), Cs (Chironomu splumosus), Cs3 (Cricontopus sp), Cs2 (Cladopelma sp.), Cs4 (Cercion sp.), Cs5 (Corixidae sp.), Ds (Dicrotendipes sp.), Es (Einfeldia sp.), Hc (Hippeutis cantori), Hs (Hippeutis cantori), Gc (Gyraulus convexiusculus), Gc2 (Gyraulus compressus), Gs (Glyptotendipes sp.), Gs2 (Gomphus sp.), Gp (Galba pervia), Lh (Limnodrilus hoffmeisteri), Ls (Libellula sp.), Os (Orthocladius sp.), Pa (Physa acuta), Ps (Propsilocerusi sp.), Ps2 (Parafossarulus striatulus), Ps3 (Polypedilum sp.), Ps4 (Procladius sp), Ps5 (Phryganea sp1.), RI (Radix lagotis), Ss (Somatochlora sp.), Ts (Tvetenia sp.), Ts2 (Tanytarsus sp.), Wp (Whitmania pigra). 


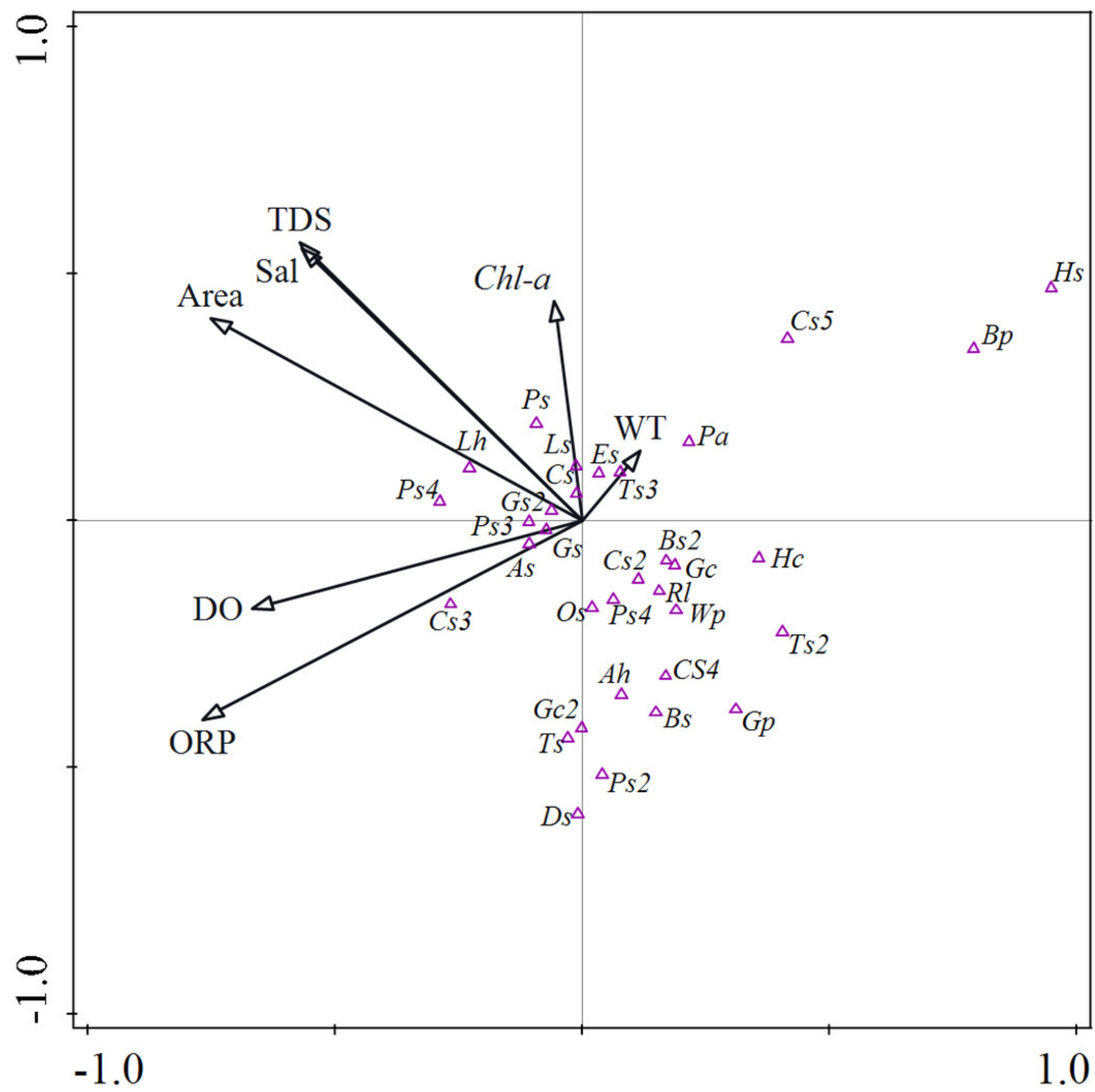

